\title{
Penggunaan Model Pembelajaran Expositori/ Model Pembelajaran Yang Berpusat Pada Guru/ Model Pembelajaran Konvensional Untuk Meningkatkan Kualitas Pembelajaran Di Kelas.
}

\section{The Use of Expository Learning Models / Teacher-Centered Learning Models / Conventional Learning Models to Improve the Quality of Classroom Learning.}

\author{
Desty Annisa Risdianti ${ }^{1} \mathrm{Nana}^{2}$ \\ ${ }^{1}$ Mahasiswa Pendidikan Fisika, Universitas Siliwangi \\ ${ }^{2}$ Dosen Pendidikan Fisika, Universitas Siliwangi \\ E-mail:182153013@student.unsil.ac.id
}

\begin{abstract}
Abstrak-
Model pembelajaran ekspositori adalah model pembelajaran yang menekankan pada proses penyampaian materi secara verbal dari seorang guru kepada sekelompok peserta didik dengan maksud agar peserta didik dapat menguasai materi pembelajaran secara optimal. Strategi pembelajaran ekspositori adalah strategi pemebelajaran yang menekankan kepada proses penyampain materi secara verbal dari seorang guru kepada siswa dengan maksud agar siswa mengusai materi pelajaran secara optimal. Tujuan utama pembelajaran ini adalah penguasaan materi itu sendiri artinya setelah pembelajaran itu berakhir siswa diharapkan dapat memahaminya dengan baik dan benar dengan cara mengungkapkan kembali materi yang telah diuraikan.
\end{abstract}

Kata Kunci: Strategi Pembelajaran Ekspositori, Kualitas Belajar Siswa

\begin{abstract}
-
The expository learning model is a learning model that emphasizes the process of delivering material verbally from a teacher to a group of students with the intention that students can master the learning material optimally. Expository learning strategy is a learning strategy that emphasizes the process of delivering material verbally from a teacher to students with the intention that students master the subject matter optimally. The main purpose of this learning is mastery of the material itself, meaning that after the learning ends students are expected to understand it properly and correctly by re-expressing the material that has been described.
\end{abstract}

Keywords: Expository Learning Strategy, Student Learning Quality 


\section{Pendahuluan}

Berdasarkan hasil observasi terhadap proses pembelajaran fisika, metode pengajaran yang masih digunakan membuat siswa sulit menerima atau menangkap topik yang disajikan. Pada saat yang sama, sebagian besar guru masih belum melaksanakan pembelajaran yang bermakna dalam mengajar, menggunakan jenis model yang lebih sedikit, dan siswa sering menghafal metode pembelajaran dengan ceramah. Siswa sering beranggapan bahwa pelajaran fisika sangat sulit dan membosankan, karena banyak rumus yang harus dihafal dan dipahami, sehingga kenyataan yang dapat dilihat adalah nilai siswa dalam pembelajaran fisika masih sangat rendah. Untuk memperoleh hasil yang sangat memuaskan dalam pembelajaran fisika, peran guru sangat diperlukan dalam menerapkan model dan strategi pembelajaran yang tepat. Oleh karena itu, dalam hal ini salah satu model pembelajaran yang coba diterapkan adalah model pembelajaran ekspositori.

Model pembelajaran ekspositori adalah model pembelajaran yang menekankan pada proses penyampaian materi secara verbal dari seorang guru kepada sekelompok peserta didik dengan maksud agar peserta didik dapat menguasai materi pembelajaran secara optimal. Keunggulan model pembelajaran ini adalah (a) dengan model pembelajaran ekspositori guru bisa mengontrol urutan dan keluasan materi pembelajaran, dengan demikian guru dapat mengetahui sampai sejauh mana peserta didik menguasai bahan pelajaran yang disampaikan, (b) model pembelajaran ekspositori dianggap sangat efektif apabila meteri pembelajaran yang harus dikuasai peserta didik cukup luas, sementara itu waktu yang dimiliki untuk belajar terbatas, (c) melalui model pembelajaran ekspositori selain peserta didik dapat mendengar melalui penuturan (kuliah) tentang suatu materi pelajaran, juga sekaligus peserta didik bisa melihat atau mengobservasi (melalui pelaksanaan demonstrasi), dan (d) model pembelajaran ini bisa digunakan untuk jumlah peserta didik dan ukuran kelas yang besar (Sanjaya W. , 2006). Selain itu, hal ini juga diperkuat dari hasil penelitian sebelumnya yaitu (Atriyanto, 2014) yang menyatakan bahwa hasil belajar peserta didik yang menggunakan strategi ekspositori lebih baik dibandingkan peserta didik yang menggunakan model pembelajaran konvensional.

\section{Metode Penelitian}

Pada penelitian kali ini, menggunakan metode penelitian studi pustaka. Metode penelitian studi pustaka adalah jenis penelitian yang digunakan untuk mengumpulkan informasi dan data secara mendalam melalui berbagai dokumen, buku catatan, majalah, referensi lain, dan hasil penelitian sebelumnya yang terkait, guna mendapatkan jawaban dan landasan teori atas pertanyaan yang akan diteliti (Yaniawati, 2020).

\section{Hasil dan Pembahasan}

\section{A. Pengertian Strategi ekspositori}

Strategi pembelajaran ekspositori adalah strategi pemebelajaran yang menekankan kepada proses penyampain materi secara verbal dari seorang guru kepada siswa dengan maksud agar siswa mengusai materi pelajaran secara optimal. Roy killen menamakan strategi ini dengan istilah pembelajaran langsung, karena dalam strategi ini materi pelajaran langsung disampaiakan oleh guru, siswa tidak dituntut menemukan materi itu. (Sanjaya W. , 2009) 
Perbedaan

ekspositori dengan metode ceramah, sebagaimana dikatakan Wina sanjaya adalah dalam strategi ekspositori bisa digunakan metode ceramah sekaligus tanya jawab bahakan diskusi degan memanfaatkan sumberdaya yang tersedia termasuk menggunakan media pembelajaran

\section{B. Prinsip-Prinsip Pembelajaran Ekspositori}

Dalam penggunaan strategi pembelajaran ekspositori terdapat beberapa prinsip yang harus diperhatikan oleh setiap pendidik, yaitu (a) Berorientasi pada tujuan, Meskipun penyampaian tema adalah fitur utama. Dalam strategi pembelajaran ekspositori melalui metode ceramah. Namun bukan berarti proses penyampaian materi tanpa tujuan. Belajar; inilah tepatnya yang harus dipertimbangkan, kunci untuk menggunakan strategi ini. Itu sebabnya sebelum strategi ini guru harus terlebih dahulu menetapkan tujuan pembelajaran yang jelas dan terukur. Sama seperti standar umum, tujuan pembelajaran harus ditetapkan dalam bentuk perilaku terukur atau berorientasi pada kemampuan siswa. (Suyadi, 2013)

Sangat penting untuk memahami hal ini, karena tujuan spesifik memungkinkan kita untuk mengontrol efektivitas strategi penggunaan belajar. Strategi pembelajaran ekspositori mungkin tidak dapat mengejar tujuan keterampilan berpikir tingkat tinggi, seperti kemampuan menganalisis, mensintesis, atau mengevaluasi sesuatu, tetapi ini tidak berarti bahwa tujuan keterampilan berpikir tingkat rendah tidak perlu diformulasikan. Tujuan inilah yang harus dijadikan ukuran penggunaan strategi ekspositori. (Sanjaya W. , 2006)

(b) Prinsip komunikasi, proses pembelajaran dapat dikatakan sebagai proses komunikasi, yang mengacu pada proses penyampaian seseorang (sumber) berita (pesan) yang dikirimkan kepada seseorang atau sekelompok orang (penerima pesan). Informasi yang ingin disampaikan adalah materi pembelajaran yang terorganisir dan terstruktur menurut tujuan tertentu yang ingin dicapai. Dalam proses komunikasi, guru adalah sumber informasi, dan siswa adalah penerima informasi.

Dalam komunikasi, selalu ada pesan (informasi) transmisi dari sumber pesan ke penerima pesan. Sistem komunikasi jika pesan secara keseluruhan dapat ditangkap oleh penerima pesan, maka pesan tersebut valid. Dan jika pesan tidak diterima dengan baik, maka sistem komunikasi tidak efektif. Jelaskan bahwa strategi menekankan pada proses penyampaian, sehingga prinsip komunikasi sangat penting. (Sanjaya W. , 2006)

(c) Prinsip kesiapan, Dalam teori belajar koneksionis, "persiapan" adalah salah satu hukum belajar. Inti dari hukum belajar ini adalah bahwa ketika semua orang siap, mereka akan merespons dengan cepat setiap stimulus; jika tidak, tidak mungkin setiap orang akan merespon setiap stimulus yang muncul ketika dia belum siap. Apa yang bisa kita pelajari dari hukum belajar adalah agar siswa dapat menerima informasi yang kita 
berikan sebagai stimulus, terlebih dahulu kita harus mempersiapkan mereka secara fisik dan psikis untuk menerima pelajaran. Ketika siswa belum siap menerimanya, jangan mulai menunjukkan topik. Sama seperti pekerjaan komputer, ketika ada file untuk menyimpan data, setiap data yang dimasukkan dapat disimpan di memori. Jika file tidak tersedia, tidak ada data yang dapat disimpan. (Suyadi, 2013)

(d) Prinsip berkelanjutan, Proses pembelajaran ekspositori harus mendorong siswa untuk mau belajar lebih banyak tentang topik tersebut. Belajar tidak hanya pada waktu itu, tetapi juga waktu berikutnya. Ilustrasi yang berhasil adalah jika dapat membawa siswa ke dalam situasi yang tidak seimbang (disequilibrium) melalui proses penyampaian, sehingga mendorong mereka untuk mencari kedamaian.

Temukan atau tingkatkan wawasan melalui proses belajar mandiri. (Suyadi, 2013)

\section{Peranan Guru dan Siswa Dalam Pembelajaran Ekspositori}

2006) Menurut Dimyati dan Mudjiono dalam bukunya yang berjudul Belajar dan Pembelajaran, peranan guru dalam strategi pembelajaran ekspositori adalah: (a) Penyusun agenda pembelajaran. (c) Pemberi kemudahan meniru yang baik. (d) Pembimbing pelajar bagian dalam tiba di masukan yang benar. (e) Penilai perolehan masukan.

Sementara kontribusi anak buah bagian dalam reka bentuk kursus ekspsositori adalah: (a) Pencari petunjuk yang benar. (b) Pemakai cara dan bibit yang benar. (c) Menyelesaikan jawatan sehubungan tambah tilikan guru.

D. Karakteristik strategi eskpositori Terdapat beberapa karakteristik strategi ekspositori, di antaranya sebagai berikut: Pertama, rancangan ekspositori dilakukan tambah kebiasaan membaca subjek hikmah secara verbal. Artinya, berkata secara suara menakhlikkan aparat patokan bagian dalam mengamalkan rancangan ini. Oleh karena itu kencang golongan mengidentikkannya tambah ceramah. Kedua, biasanya subjek hikmah yang disampaikan adalah subjek hikmah yang beres jadi, serupa petunjuk atau fakta, rancangan-rancangan terpatok yang harus dihafal sehingga tidak menghimpit cantrik kepada bergerak ulang. Ketiga, sasaran patokan pemberadaban ini adalah pendudukan subjek hikmah itu sendiri. Artinya, setelah trik pemberadaban kiamat cantrik diharapkan bisa memahaminya tambah tepat tambah kebiasaan bisa mengekspresikan pulih subjek yang sangka diuraikan. (Majid, 2013)

dilakukan dengan cara menyampaikan materi utama dalam melakukan strategi ini, sering orang mengidentikkan dengan metode ceramah, (2) Biasanya materi pelajaran yang sudah jadi, seperti data atau fakta, konsep-konsep tertentu yang harus dihafal sehingga tidak menuntut siswa untuk berfikir ulang. (3) Tujuan utama pembelajaran ini adalah penguasaan materi itu sendiri artinya setelah pembelajaran itu berakhir siswa diharapkan dapat memahaminya dengan baik dan benar dengan cara 
mengungkapkan kembali materi yang telah diuraikan. ( Dimyati dan Mudjiono, 2006) Dimyati dan mujiono menambahkan bahwa tujuan utama pengajaran ekspositori adalah memindahkan pengetahuan, keterampilan dan nilai-nilai kepada siswa. Hal yang esensial pada bahan pengajaran harus dijelaskan kepada siswa.

E. Kelebihan dan kekurangan Strategi Ekspositori

(Sanjaya W. , 2006) Menurut Wina Sanjaya kelebihan dan kekurangan dari strategi ekspositori adalah

\section{Kelebihan Ekspositori}

Strategi

(Abdurrahman, 2012) Strategi ini banyak digunakan dan beberapa manfaat dari strategi presentasi antara la in: (a) Guru dapat mengontrol urutan dan ruang lingkup materi. (b) Strategi bisa sangat efektif bila menggunakan berbagai bahan.

(c) Jumlah siswa yang digunakan dalam jumlah banyak dan siswa.

2. Kekurangan

Strategi

Ekspositori

(Abdurrahman,

Selain kelebihan, strategi prese ntasi juga memiliki kelemahan sebagai berikut: (a) Biasanya diimplementasika $\mathrm{n}$ melalui bahasa. (b) Keberhasi lan strategi pembelajaran interpretatif sang at tergantung pada keterampilan guru. (c) Kemampuan untuk me ngkonfirmasi pemahaman sisw a tentang mata pelajaran sangat terbatas.

\section{F. Langkah-langkah ekspositori}

(Sanjaya W. , 2006)

\section{Persiapan}

Persiapan merupakan langkah yang sangat penting. Keberhasilan pelaksanaan pembelajaran dengan menggunakan ekspositori sangat bergantung pada langkah persiapan tujuan yang ingin dicapai dalam melakukan persiapan adalah: (a) Mengajak siswa keluar dari kondisi mental yang fasif (b) Membangkitkan motivasi dan minat sisw untuk belajar (c) Merangsang dan menggugah rasa ingin tahu siswa (d) Menciptakan iklim dan suasana yang terbuka (e) Memberikan sugesti yang positif (f) Mulailah dengan membuka tujuan yang harus dicapai.

\section{Penyajian}

Penyajian adalah langkah penyampaian materi pembelajaran sesuai dengan persiapan yang telah dilakukan yang harus dipikirkan oleh guru dalam penyampaian ini adalah bagaiman agar materi pelajaran dapat dengan mudah ditanngkap dan dipahami oleh siswa.

\section{Menghubungkan}

Langkah korelasi adalah langkah menghubungkan materi pelajaran dengan pengalaman siswa atau dengan hal-hal yang memungkinkan siswa untuk menangkap keterkaitan yang telah dimiliki.

\section{Menyimpulkan}

Menyimpulkan tahapan untuk memahami inti dari materi pelajaran yang telah disajikan langkah penyiimpulan adalah langkah yang sangat 
penting dalam strategi ekspositori. Sebab melalui langkah siswa akan dapat mengambil intisari proses penyajian.

\section{Penerapan}

Langkah penerapan ini merupakan langkah yang penting dari proses pembelajaran ekspositori sebab melalui langkah ini guruakan dapat menyimpulkan informasi tentang penguasaan dan pemahaman materi pelajaran oleh siswa.

\section{Kesimpulan}

Untuk memperoleh hasil yang sangat memuaskan dalam pembelajaran fisika, peran guru sangat diperlukan dalam menerapkan model dan strategi pembelajaran yang tepat. Oleh karena itu, dalam hal ini salah satu model pembelajaran yang coba diterapkan adalah model pembelajaran ekspositori.

\section{Daftar Pustaka}

Abdurrahman, M. (2012). Pendidikan Bagi Anak Berkesulitan Belajar: Teori
Diagnosis, dan Remediasinya. Jakarta: PT.Rineka Cipta.

Atriyanto, B. \&. (2014). Pengaruh Strategi Pembelajaran Ekspositori Terhadap Hasil Belajar Peserta didik pada Mata Diklat Memperbaiki Compact Cassete Recorder Kelas XI TAV di Sma Negeri 2 Surabaya. Jurnal Pendidikan Teknik Elektro, 3(2), 09-13.

Dimyati dan Mudjiono. (2006). Belajar dan Pembelajaran. Jakarta: Rineka Cipta.

Majid, A. (2013). Strategi Pembelajaran. Bandung: PT Remaja Rosdakarya.

Sanjaya, W. (2006). Strategi Pembelajaran Berorientasi Standar Proses Pendidikan. Jakarta: Kencana Prenadamesia Grup.

Sanjaya, W. (2009). Kurikulum dan Pembelajaran. Jakarta: Kencana.

Suyadi. (2013). Strategi Pembelajaran Pendidikan Karakter. Bandung: PT. Remaja Rosdakarya. 